\title{
Polysèmes
}

Revue d'études intertextuelles et intermédiales

\section{In-Yer-Face Mouths and Immobilisation: Parodies of Samuel Beckett's Theatre by Sarah Kane}

\section{Lara Cox}

\section{OpenEdition}

1 Journals

\section{Electronic version}

URL: http://journals.openedition.org/polysemes/7551

DOI: 10.4000/polysemes.7551

ISSN: 2496-4212

Publisher

SAIT

\section{Electronic reference}

Lara Cox, «In-Yer-Face Mouths and Immobilisation: Parodies of Samuel Beckett's Theatre by Sarah Kane », Polysèmes [Online], 23 | 2020, Online since 30 June 2020, connection on 02 July 2020. URL http://journals.openedition.org/polysemes/7551; DOI : https://doi.org/10.4000/polysemes.7551

This text was automatically generated on 2 July 2020.

Polysèmes 


\title{
In-Yer-Face Mouths and Immobilisation: Parodies of Samuel Beckett's Theatre by Sarah Kane
}

\author{
Lara Cox
}

1 Chris Lee's parody of Sarah Kane's theatre, entitled Crushed, involves a head being obliterated by a man wielding a baseball bat. The head is then urinated, defecated, and masturbated on before a talking tree and the violent man explode to the nihilistic cry "Fuck you all" uttered by an unknown agent (Saunders 2009, 4). If I begin this article with the Lee vignette, it is to demonstrate that Sarah Kane, known for her sexually explicit, brutal drama, has typically been constructed as the object of parody, not its initiator. During her short life (she committed suicide at the age of twenty-eight), she was cruelly mocked by the tabloid press; for instance The Daily Mail's Jack Tinker dubbed her first play Blasted "The Disgusting Feast of Filth" (1995) for its act of cannibalism, two rapes, defecation, and bloody murder. Kane has earned a posthumous place in the "New Brutalist" or "In-Yer-Face" theatre movement, which emerged in Britain in the late nineties. In-Yer-Face theatre, including such full-frontal plays as Shopping and Fucking by Mark Ravenhill (1996), sought to play on spectators' visceral reactions to jolt them out of the political inertia that characterised the "Cool Britannia" nineties, a decade marked by events such as the formation of the Spice Girls and the rise of Blairite middle-class socialism. Crushed raised howls of laughter when first performed at a theatre conference in Copenhagen in 2004. The audience perhaps recognised, maybe even revered, Kane's ultra-brutal stamp, but the parody also references the revulsion at a violence deemed morally indefensible felt by the tabloid press in the early days of her reception.

2 Yet the Lee parody aptly conjures the traces of Samuel Beckett, whose theatre Kane listed as one of her influences: the exploding tree recalls the lone tree in Waiting for Godot (1955), Vladimir and Estragon's only constant onstage witness to their eventless drama; the disembodied head summons up Beckett's Winnie whose entire body is immersed in a mound of dirt leaving nothing visible but her face at the end of 
Happy Days (1961). The final "Fuck you all" could be construed as a reference to Beckett's Rockaby (1981), which closes with the line "Fuck life". Crushed not only mocks what Kane is most known for, verbal and physical violence, but also exposes a parody within a parody: Kane's own parodic recasting of Beckett, which I explore in this essay. ${ }^{1}$

I posit that Kane parodies Beckett in order to make a commentary on gender. This develops on from Elaine Aston's feminist re-reading of Kane's theatre. Known as the lone "ladette" among a flurry of male authors of an In-Yer-Face aesthetic (Mark Ravenhill, David Eldridge and so on), Kane repudiated any feminist goal for her theatre, but, in the brutality of Kane's theatre, Aston opines that the playwright "contests the "normalising" forces through which the sexes are kept in place, by making us feel the violence of the symbolic masculine" (80-81). Kane's parodying of Beckett, as I explore, enables a critique of hegemonic gender constructions in multiple arenas: in Beckett's writing and his career, but also in the wider society. As Simon Dentith puts it, contesting a strict formalist definition of parody advanced by linguists such as Genette and Bakhtin by giving the example of Dickens's Bleak House parody of workingclass London accents, "[p]arody includes any cultural practice which provides a relatively polemical allusive imitation of another cultural production or practice" (9) (emphasis mine). Parody can critique the earlier text that it imitates, but it may also "draw on the authority of precursor texts to attack, satirise, or just playfully to refer to elements of the contemporary world". Three of Kane's plays, Blasted (1995), Crave (1999), and 4.48 Psychosis (1999), will be analysed for their parodic rewritings of Beckett's work, notably the latter's Waiting for Godot and Not I (1972). Kane's parodies serve to deconstruct male dominance in Beckett's plays, in his production practice, and even in his self-constructed posthumous legacy. However, they also imitate Beckettian motifs in a way that looks more kindly on Beckett, in order to scrutinise gender hierarchy in the wider world.

4 I am not the first to connect the two playwrights (Angel-Perez 2006, Saunders 2010, de Vos 2011, Sierz 2014) but the argument that it is through the playfulness of parody that Kane re-views Beckett does allow me to bypass a tendency in critical literature to submerge Kane's voice, perhaps to legitimise it, in pathos, tragedy, and an "In-YerFace" violence turned inward as the playwright committed suicide in $1999 .{ }^{2}$ A reading of parody in Kane claims the benefit of confirming, much to critics' "surpris[e] [...] given the bleakness of her work, that she possessed a sense of humour" (Urban 304).

\section{Blasting Beckettian bodies}

5 Blasted, Kane's first published play, debuted at the Theatre Upstairs in the Royal Court in London in the same week that an earthquake struck Japan and a girl had been raped and murdered in a UK wood. Yet Kane's play, involving a double rape, got more coverage in the tabloids than either of these two real-life tragedies. Middle-aged tabloid journalist Ian rapes his girlfriend Cate in a hotel room. A soldier enters, taking cover from a nameless war outside, and, in turn, rapes and mutilates Ian. The latter oscillates between verbal and physical abuse, and dulcet declarations of love, with his girlfriend Cate in the first, naturalistic half of the play. Meanwhile, a war rages on outside their Leeds hotel room. In the play's second half, Naturalism turns to graphic Surrealism (Saunders 2009, 52): a soldier enters and rapes and kills Ian by eating his eyes; Ian is resurrected and eats a dead baby that Cate brings in from the war outside; 
Ian finally crawls into a hole with only his "head poking out of the floor" (Kane 1995, 60) while Cate feeds him a sausage and gin. Kane wrote the play during the Srebrenica genocide (1995) of the Bosnian war. The connections Blasted made between domestic violence (Ian's rape of Cate) in the seemingly protected "cool Britannia" and the brutality of a far-off conflict (the soldier's rape of Ian) were made visible, a gesture that failed to stymie journalists' outrage. Guardian theatre reviewer Michael Billington went so far as to call for the playwright's institutionalisation (Saunders 2009, 52) (before changing his mind about Kane's talent in later years).

6 Kane's Blasted described her intention to demonstrate that "the logical conclusion of the attitude that produces an isolated rape in England is the rape camps in Bosnia" (qtd. in Urban 308). Both are undergirded by "the way society expects men to behave" (Urban 308). Recasting Beckettian motifs helps Kane to criticise the violence of masculinity. Ian is a pale version of an oft-forgotten character in Waiting for Godot: the boy. The latter acts as the intermediary between the characters Vladimir and Estragon and the title character, Godot, whose arrival the former two so desperately await in vain. Vladimir and Estragon insist to the transient boy, "tell him you saw us" (56) and this becomes Vladimir's more desperate "tell him that you saw me...that you saw me" (106) in the second act of the play. The boy promises to transmit this message but is, each time, the woeful bearer of the news that the title character will not appear on that day, prolonging the characters' intolerable wait.

7 In Blasted, these lines are repeated with similar insistence by the soldier, who solicits tabloid journalist Ian to relay the full horrors of the war to the general public: "Tell them you saw me / Tell them...you saw me" (48). Mark Taylor-Batty (2014) positions this paraphrasing of Beckett in Blasted as part of an ethical strategy to engage the spectator in enquiring into the reality of the Bosnian war behind the media's false narratives that downplayed the conflict's full horror of mutilation, rape, and murder. Yet, this could also be an instance of parody since Ian, Blasted's messenger, is a grotesque version of Godot's character. Beckett's boy in Godot agrees, albeit helplessly, to transmit the message of the titular character's non-arrival, whereas Ian actively refuses the soldier's request in Blasted to pass on the message about the horrors of the war to the general public. Ian states that his tabloid's readership prefers salacious renderings of domestic rape cases involving "[k]inky car dealer[s]" (48) to en masse cases of sexual abuse in a far-off war. A rather innocent boyhood in Godot becomes a sinister adult masculinity in Blasted. The cross-reading enables a confrontation of the way male dominance informs what is reported by the media. Ian embodies a repulsive hegemonic masculinity of the tabloid industry, known for "page 3" nude pictures of women. But Ian's manhood is so hyperbolic and conceited that he easily stirs up audience deconstruction of the power linked to his gender: in addition to racist remarks about "wog[s]" (3) serving him at the hotel and homophobic dismissals of "dykes" "[s]ucking gash" (19), he clutches his groin in a demonstration of his male potency. Such acts could be construed, in their sheer proliferation and exaggeration, as in line with the playful thrust of parody.

8 As Linda Hutcheon states, parody involves an imitation of a cultural text that can range from "scornful ridicule" to "reverential homage" (37). Transforming Beckett's boy messenger in Godot into a middle-aged male journalist in Blasted would suggest a degree of "reverential homage" paid by Kane to Beckett; Beckett's boy character is valorised, his innocence highlighted by Kane's depiction of an oafish and self-interested adult 
male messenger of tabloid journalism, Ian. Yet the playwright described Beckett's influence on her, particularly in relation to Blasted, in ambivalent terms:

I think my influences are quite obvious. Yes, Beckett, of course, but not particularly consciously because I'm practically unconscious when I write and I think once you're consciously influenced your voice becomes inauthentic. But I was steeped in Beckett so it's not surprising that Blasted ends with an image of a man poking out of the floor with the rain pouring through the ceiling onto his head. (Saunders 2009, 46)

9 The metaphor of being "steeped" in Beckett positions him as akin to an intoxicant enriching the taste of a multi-layered cake, but it may imply saturation-"steeped" as opposed to "sprinkled with" or a more overtly positive "enhanced by". Indeed, scrutinising the ending of Blasted suggests more of parody's "scornful ridicule" of Beckett than "reverential homage".

Beckett had a fascination with creating images of the "partial body" as Julie Campbell describes (161). Not I displays a woman's mouth floating in the darkness. Likewise, in Play (1964) the heads of two women and one man emerge from urns. Similarly, at the end of Kane's Blasted, as part of Ian's downfall after being raped and mutilated by the soldier, Ian crawls into a hole in the floorboard, his head emerging from the floorboards with rain falling down on him to cement the image of misfortune. This echoes the character of Winnie from Beckett's Happy Days who clutches an umbrella while her lower half is immersed in a mound. Her body becomes progressively submerged until audiences can see nothing but her head. The Beckettian image is evoked in Blasted to aid in a depiction of Ian's downfall, but words from the character's girlfriend Cate indicate a certain degree of ridicule and lack of sympathy for Ian's sorry state:

Cate: You're sitting under a hole

Ian: I know

[...]

Cate: Stupid bastard. (60)

Putting words to Ian's action draws attention to their absurdity, which is only emphasised by Cate's end insult. Despite the gravity of the dramatic action (two rapes, one war, one murder, and a death), the words "You're sitting under a hole" produces a humour that is suggestively turned against the originator of these theatrical partial bodies, Beckett himself.

12 As Aston remarks, we cannot help noticing a gender reversal of the Beckettian partial body: whereas "Winnie is buried up to her neck in sand" in Happy Days "Ian visibly disintegrates and is [...] forced into the passive position of the "feminine"" in Blasted (56). Parody's "repetition with a difference" (Hutcheon 37) of Beckett's immobilised bodily bits leads us to reflect with "scornful ridicule" (Hutcheon) on the playwright's tendency to cage female bodies disproportionately: the mouth in Not I and the moundcum-head in Happy Days are those of women and the heads-cum-urns in Play are predominantly women (two women and one man). Beckett's male characters, on other hand, tend to be mobile (Campbell 162), although there are some important exceptions to this. ${ }^{3}$ In any case, Kane's progressive weakening of Ian until he is nothing but a head emerging from the floorboards merely makes visible in fiction a violence that Beckett committed on women's bodies in real life in his role as director or through his stage directions. Billie Whitelaw told of the unbearable pressure mounting to her head clamped in by a vice in her enactment of the floating mouth in Not $I$ and of her twisted 
spine in her role in Footfalls, both directed by Beckett himself; Irene Worth, who played Winnie in Andrei Serban's version of Happy Days, recounted suffering from muscle spasm in remaining too long in her mound (Campbell 170). Since Ian in Kane's Blasted moves from a full-bodied, groin-clutching man to a helpless head, the parody dramatizes the fact that the real-life female body "is worked, violated even, much like the raw materials of painter or sculptor" in Beckett (Chabert 161).

\section{Everything to be done: from Godot to Crave}

"Nothing to be done" is the famous line that opens Waiting for Godot as Estragon struggles and fails to take off his boot. Betraying ironic defeatism (Estragon continues with his boot ad infinitum), the line is repeated to describe everything from the immutability of personality traits to the characters' inability to laugh. In Kane's Crave (1998), her penultimate play, the Beckettian catchphrase finds itself immersed in a text that, as Aston points out, is a palimpsest of previous works, from the Bible to T.S. Eliot, Shakespeare, other Beckettian works, and even the highly mediatised image of "Napalm girl", the girl Kim Phúc who was captured running away from her burning village covered in the chemical substance (95). There is nothing particularly special about the use of Beckett's line given this inter-textual framing, but it does encapsulate what I shall argue to be Kane's ironic reworking of Beckett not only at a level of text, but also at the level of his approach as a director and protector of his legacy.

14 "Nothing to be done" is recuperated in Crave for a brief interchange between the characters of " $\mathrm{A}$ " and " $\mathrm{C}$ ", the former being an older man who seduced and abused the latter, who is a young girl. The characters' conversation crosses with that of "B", a younger man, and " $\mathrm{M}$ ", his older mistress. The older and younger women, $\mathrm{M}$ and $\mathrm{C}$, find connections in their experiences of being deceived by men:

M: When he's generous, kind, thoughtful and happy, I know he's having an affair.

C: He thinks we're stupid, he thinks we don't know.

M: A third person in my bed whose face eludes me.

B: Just me.

A: Just the way I am,

C: Nothing to be done. (30)

"Nothing to be done" is either a line that echoes the older male A's declarations of sincerity "Just the way I am" or is an ominous re-purposing of Beckettian defeatism that bespeaks the younger girl C's entrapment in a cycle of abuse that she can't escape. The polysemous nature of Crave's "Nothing to be done" emulates the multiple uses of the phrase in the original Godot and as such suggests a degree of "reverential homage" (Hutcheon 37) paid by Kane to the intricacy of Beckett's language games.

Yet "scornful ridicule" (Hutcheon 37) of the playwright could be detected too in the reinvestment of the Beckettian line "Nothing to be done" in a story that is ambivalent about paedophilia. This was only added to be the chat-show setting of Crave's first production directed by Vicky Featherstone and debuting at the Edinburgh festival in 1998, itself a possible parody of Beckett's later play Rockaby (1981). Featherstone emphasised the confessional overtones of the play, the "craving" of each of the characters for love, positioning each of them in spotlighted seats, in which they remained throughout the performance. In Beckett's Rockaby (1981), an old womansimilarly named by a single letter, "W"-remains immobile but for a methodical 
rocking in her chair as her recorded circuitous monologue of loneliness and waiting for death plays in the background. The chat-show setting to the line "Nothing to be done", associated with the sleaze of shows like Jerry Springer and Trisha (UK), suggests the ludic repetition at the heart of parody that could be argued a self-conscious "cheapening" of one of Beckett's earliest and last plays, Godot (1955) and Rockaby (1981).

I posit this notion of Kane's "cheapening" of Beckett not disapprovingly. Kane's theatre plays with Beckett's lines and stage directions that he himself deemed untouchable, leaving little room for the experimentation and adaptability of new practitioners. In the years leading up to his death, Beckett became increasingly protective of his legacy, handing over control of his estate to his nephew Edward shortly before his death in 1989 to carry out Beckett's wishes about the way they should be performed. In 1992, a court ruling seeking to prevent the "violation of Beckett's moral rights" forbade the casting of female leads in Waiting for Godot (Billington 2006), giving to the words "Nothing to be done" that are so central to the play new meaning about the primacy of the playwright's wishes in the process of production. Beckett was against, and perhaps reacting to, the tide in his demands: theatre scholars over the past thirty years have impugned progressively the authority of the playwright's text in performance, deeming it undemocratic in the collaborative process of theatre making.

18 The line "Nothing to be done" captures Beckett's increasing control over his work even following his death. By contrast, the words "Nothing to be done" in Kane's Crave is a rather ironic statement about the playwright's move towards an opposite relinquishing of her hold on the performances of her plays. Along with her last play 4.48 Psychosis (1999), Crave contained no stage directions, which Graham Saunders characterises as Kane's move towards a "poetic drama" $(2009,32)$. Kane had no prescriptive ideas about the staging of Crave (Saunders 2009, 94) and, unlike Beckett's treatment of his female actors, she was critical of "the ludicrous demands set by [her] text" and Featherstone's "insistence on performance" when actor Paul Hickey, playing B in Crave, lost sensation on one side of his face through hyperventilation (Saunders 2009, 79). Indeed, in an almost completely opposite process to the shoring up of the Beckettian estate and instructions for performance, Kane published Crave under the pseudonym Marie Kelvedon, whose bibliography featured in the first version of the play. The bibliography's outlandish details-Kelvedon's "unspeakable act of Dadaism", her performance happening performed through a canteen hatch to an audience of one person, and her time as a roadie for the Welsh band called the Manic Street Preachers (Urban 304)-connote a playfulness and sense of humour that take Kane far away from Beckett's protective concerns about his legacy.

19 In short, I am suggesting that we interpret the stage-directionless Kane's Crave as a parodic rewriting of Beckett's Waiting for Godot in the years after the latter's death. Kane's "Nothing to be done" acquires a degree of irony in this case, since she welcomed the idea of "everything [...] to be done" in terms of the performance and production exploration of Crave. This is of course a speculative reading; it cannot be bolstered by empirical claims of Kane's intention to parody Beckett's protectiveness over his legacy. Kane's cynicism about her own authority may be symptomatic of her self-doubt or it may be explained contextually by the move over the past three decades towards demolishing the authority of the play-text in theatre practice, favouring instead the fruits of collaboration in the rehearsal process (for example, Harding 2000). However, since Kane was "steeped" in Beckett, as we recall, to claim an unintentional parody of 
Beckett's close handle on his legacy allows us to reflect scornfully, recalling Hutcheon's definition of parody, on the closure of the Irish playwright's texts to experimentation. Indeed, this reading adds Kane's voice to the body of critical literature in recent times on the Beckett estate's reticence to aesthetic renewal. ${ }^{4}$ This culminated in the 1992 court ruling over male leads in Godot.

\section{In-Yer-Face mouth: from Not I to 4.48 Psychosis}

Structurally and thematically, Kane's 4.48 Psychosis closely resembles Beckett's Not I: both put onstage the plight of a woman suffering from mental illness, tell of the heroine's troubled upbringing, and fail to relay a coherent narrative. Both are guided by refrains which signal the play's respective titles: Mouth utters five times a chorus of "What...who?...no!...she!", encapsulating her inability to tell her story in the assured voice of the first person, which makes sense of the title Not I; Kane's heroine rebounds upon the phrase "At 4.48" explaining her desire to commit suicide at the eponymous time, again a total of five times. These song-like echoes between Not I and 4.48 demonstrate what Graham Saunders labels similar "concentration[s] on the rhythm of language" $(2010,77)$ linking Kane's and Beckett's oeuvres. In performance, Martin Harries quipped in a review of the 2005 production of 4.48 Psychosis, directed by Claude Régy, at the Brooklyn Academy of Music (BAM), “imagine Beckett's Not I staged for almost nine hundred spectators" (6). Harries later explained that like Not I's "unmoving actress, only her mouth visible", Régy's 4.48 featured actress and French cinema star Isabelle Huppert not once "shift[ing] the position of her feet [...] indeed, scarcely moved" (8). Though the text of Beckett's Not I featured a cloaked Auditor giving a periodic shrugging gesture of incomprehension, Régy added the figure of an uncomprehending therapist placed behind a scrim to Kane's play, thus further giving weight to Harries's view that "dramaturgically Régy translated 4.48 Psychosis as [...] Not I " (8). These forms of aesthetic and performative "repetition that includes difference" (Hutcheon 37) confirm the idea that 4.48 Psychosis may be considered a parody of Not I.

Concentrating on a comparison of the Régy production with Beckett's own version of Not I, staged at the Royal Court in 1973, I posit that Kane's play affords this look back at Not I filled with "scornful ridicule" (Hutcheon 37) for what the latter fails to tell audiences about the way women with mental health problems are treated in our society. A number of feminists have written on the disproportionate institutionalisation of women by the psychiatric establishment, explaining that historically, women have been pegged as insane as punishment for their transgression of gender norms (see Chesler, Ussher, Appiganesi). Amy Lehman explores the way psychiatric punishment for gender failure and theatre history have intersected, as nineteenth-century psychologist Jean-Marie Charcot asked his women patients diagnosed with a mental illness to perform the role of Shakespeare's Ophelia, who is driven to insanity for defying her father Polonius and for lying to her suitor Hamlet, and who thus fails to be either a faithful daughter or achieve the role of good wife (Lehman 30). The Régy production of 4.48 Psychosis did not sentimentalise the heroine's eponymous experience of psychosis in order to counter this misogynist history; instead, Régy and Huppert worked together to create an image of simultaneous "being" and "non-being" (Baron Turk 30), showing the heroine's humanity but also the dehumanising toll of madness. Huppert was dressed in black leather trousers and a 
simple t-shirt, and she placed her feet in a small rectangular shaft of light. The chiaroscuro effect created by this combination, reinforced by lighting director Dominique Bruguière's periodic changes of the rectangular spotlight from white to red, had the effect of giving nuance to Huppert's facial features, emphasising a contrast between the star's lack of expression, which as a number of reviewers remarked was akin to a statue, and the few tears welling up in the actress's eyes. ${ }^{5}$ I have written elsewhere on Huppert's trademark ability to convey agency in impassive expression (see Cox 2012). In her cinematic roles as the eponymous characters of La Dentellière (Claude Goretta, 1977) and Gabrielle (Patrice Chéreau, 2005), she vanquishes her male abusers (Claude Chabrol, 1991) by means of a glazed and inscrutable look. Huppert termed this glazed expression the creation of an inner alterity. Her expressionless face enables her to convey her heroine's self-escape from distressing situations (Cox 2013). This capacity to convey agency through minimal action was recycled for the Régy production: Huppert's statuesque impassiveness was harnessed to convey, as Harries states, the notion of a "willed refusal to move" (12) or "decisive immobility" (13).

Taken as parody, Régy's 4.48 Psychosis highlights the extent to which Mouth is dehumanised in Beckett's 1973 production of Not I. Mouth literally lacks the singularity of a human face. In the 1973 production all that audiences saw was a pair of lips floating in the darkness, an effect Beckett achieved by clamping actress Whitelaw's head into a vice, and painting her face black and her lips bright red. Complete with suggestive saliva beads on the invisible chin, this image is, as Ann Wilson (1990) describes, redolent of the objectification of women in pornography. Mouth is reduced to a hypersexual synecdoche of her gender as two red lips, demonstrating radical feminist Phyllis Chesler's contention, in her 1972 book Women and Madness, that madness is "a penalty for "being [too] female as well as daring not to be" (39). Huppert parodies Mouth's facelessness by giving her heroine only a half-human face, between the tear-filled eyes of someone eliciting sympathy for her suffering and a statuesque impassivity-conceived as a volitional stasis (Harries) as opposed to Whitelaw's enforced immobilisation in a vice. Though Whitelaw's vice in Not I might have implied the traces of a violent medical establishment, the vice's invisibility absented all possibility of understanding the heroine in terms of the brutality she suffers at the hands of psychiatrists. By contrast, Huppert's voluntary impassivity provided a oneupmanship on an explicitly blamed medical establishment's efforts to "deadloc[k]" (Kane 2002, 7) the heroine with medical drugs, the "smooth psychiatric voice of reason" (7) and a "chemical lobotomy [that] [...] shut[s] down the higher functions of [her] brain" (19).

In other words, Huppert, Kane, and Régy scrutinise the psychiatric root of the heroine's troubled mental state, and additionally evoke a structural male domination that undergirds this. In the text, it is pointedly males who judge, objectify and restrain her. This is only brought home in the Régy production with the figure of Gérard Watkins, placed behind a scrim, who acts the uncomprehending idiot and whose voice is "false, defeated in advance" (fausse, vaincue d'avance) (Le Monde, 7 October 2002). This production, as a parody of Not I, shows the shortcomings in Beckett's vision of female madness, which lacks explicit descriptions of biomedical submission. Even the figure of the periodically shrugging Auditor in Not I, thought to be a potential trace of an 
incompetent therapist, has been deemed too elusive and thus an extraneous stage direction by a number of critics (for example, Mars-Jones 2014).

This article has explored the multi-faceted effects of Kane's parodies of Samuel Beckett's oeuvre: Beckett is parroted to elucidate male domination in the tabloid press (Blasted), to critique his tendency to constrain female bodies textually and in production (Blasted, 4.48 Psychosis) and to spotlight Beckettian closure to stage innovation posthumously (Crave). But given theatre's ability to reinvent itself with every new performance, it seems appropriate to end with how Kane's theatre shows possibilities for Beckett's plays to descend from the "metaphysical" realm (Nightingale) to the socially concrete (if the Beckett estate will allow it). We should ask ourselves how Godot may critique male dominance if the boy messenger were played by the repugnant Ian of Kane's Blasted; or how Not I, reinvigorated with a face expressing both being and non-being and an Auditor embodying male medical incompetence from Kane's 4.48 Psychosis, may communicate Mouth's suffering in ways that speak about the sexism and misogyny of the psychiatric establishment.

\section{BIBLIOGRAPHY}

Angel-Perez, Élisabeth. Voyages au bout du possible. Les théâtres du traumatisme de Samuel Beckett à Sarah Kane. Paris : Klincksieck, 2006.

Appignanesi, Lisa. Mad, Bad and Sad: A History of Women and the Mind Doctors from 1800. London: Hachette, 2002.

Aston, Elaine. Feminist Views on the English Stage. Cambridge: CUP, 2009.

Baron Turk, Edward. French Theatre Today: The View from New York, Paris, and Avignon. Iowa City: U of Iowa P, 2011.

Beckett, Samuel. Waiting for Godot. London: Faber \& Faber, 1995.

Billington, Michael. "Beckett Estate Fails to Stop Women Waiting for Godot". Guardian 4 February 2006. https://www.theguardian.com/world/2006/feb/04/arts.italy (last accessed 8 April 2020).

Buning, Marius, et al. (eds.). Pastiches, Parodies \& Other Imitations: Samuel Beckett Today. Amsterdam: Rodopi, 2002.

Campbell, Julie. “The Entrapment of the Female Body in Beckett's Plays in Relation to Jung's Third Tavistock Lecture”. Samuel Beckett Today / Aujourd'hui 15 (2005): 161-172.

Chabert, Pierre. “The Body in Beckett's Theatre'. Journal of Beckett Studies 8 (1982): 23-28.

Chesler, Phyllis. Women and Madness. New York: Doubleday, 1972.

Cox, Lara. "Going Global: The Stars of French Theory and French Cinema". Journal of Romance Studies 12. 2 (2012): 59-74.

Cox, Lara. "Flaubert, Femininity, and Free-Fall Stardom: A Reading of Madame Bovary (Chabrol, 1991) and Un cœur simple (Laine, 2008)”. Modern \& Contemporary France 21 (2013): 537-555. 
De Vos, Laurences. Cruelty and Desire in Modern Theatre: Antonin Artaud, Sarah Kane, Samuel Beckett. Madison: Fairleigh Dickinson UP, 2011.

Dentith, Simon. Parody. London: Routledge, 2000.

Harding, James (ed). Contours of the Theatrical Avant-garde: Performance and Textuality. Ann Arbor: U of Michigan P, 2000.

Harries, Martin. "Still: Sarah Kane after Beckett and Joy Division”. Modern Drama 60 (2017): 1-24.

Hutcheon, Linda. A Theory of Parody: The Teachings of Twentieth-Century Art Forms. Chicago: U of Illinois P, 1985.

Kane, Sarah. 4.48 Psychosis. London: Methuen Drama, 2002.

Kane, Sarah. Blasted (1995). London: Bloomsbury, 2011.

Lehman, Amy. Victorian Women and the Theatre of Trance. Jefferson: McFarland, 2009.

Mars-Jones, Adam. "Not I". London Review of Books 36.5 (2014): 22.

Nightingale, Benedict. "Review of Blasted". The Times 3 April 2001.

Reid, Cameron. "Screenings for Beckett in Modern Film: Ghostly Presences and Popular Cultural Manifestations". P.J. Murphy and Nick Pawliuk (eds). Beckett in Popular Culture. Jefferson: McFarland and Co, 2016, 85-98.

Saunders, Graham. About Kane: The Playwright and the Work. London: Faber \& Faber, 2009.

Saunders, Graham. “The Beckettian World of Sarah Kane”. Sarah Kane in Context. Manchester: Manchester UP, 2010.

Sierz, Aleks. In-Yer-Face Theatre: British Drama Today. London: Faber \& Faber, 2014.

Taylor-Batty, Mark. "How to Mourn: Kane, Pinter and Theatre as Monument to Loss in the 1990". Ethical Speculations in Contemporary British Theatre. London: Palgrave: 2014.

Tinker, Jack. “The Disgusting Feast of Filth”. Daily Mail, 19 January 1995: 5.

Urban, Ken. "Sarah Kane". The Methuen Guide to Contemporary British Playwrights. London: Bloomsbury, 2011.

Ussher, Jane M. The Madness of Women: Myth and Experience. London: Routledge, 2011.

Wilson, Ann. “'Her Lips Moving': The Castrated Voice of Not I". Women in Beckett: Performance and Critical Perspective. Urbana: U of Illinois P, 1990.

\section{NOTES}

1. Indeed, another level of parody is potentially added to this: Beckett himself has been considered a parodist of the Surrealists, Nietzsche, Schopenhauer and psychoanalysis, as the contributors of Pastiches, Parodies and Other Imitations explore. See Buning et al.

2. Aleks Sierz complains of critics' and gothic fangirls' conversion of Kane into "Saint Sarah" (Saunders 2009, 124).

3. For instance, the maleness and immobility of the character of Hamm in Endgame (1957) are emphasized by virtue of his contrast with his playing partner Clov, who is confined to the kitchen as his servant and is made to wear a blonde wig to parody women's reduction to domesticity, but who is the only character not immobilised since he is unable to sit. 
4. For instance, Cameron Reid critiques the Beckett estate's "near-obsessive control over professional performances of Beckett's plays", citing the "dead controlling hand" experienced by Neil Armfield in his Sydney production of Waiting for Godot in Sydney in 2003 (86).

5. For example, « Une statue sculptée dans le cauchemar du monde. » Le Monde. 7 January 2002.

\section{ABSTRACTS}

This article positions the work of British playwright Sarah Kane as a parody of the theatre of Samuel Beckett. Kane's "In-Yer-Face" style of theatre is considered as both paying homage to her idol Beckett as well as a critique of the Irish playwright's representations of women. The article argues that Kane's Blasted (1995) parodies Beckett's Waiting for Godot (1955) and in doing so elucidates male domination in the world of the British tabloid press that Kane depicts in Blasted. The article also posits that Beckett's tendency to constrain female bodies in his plays is impugned via parody in Kane's Blasted and 4.48 Psychosis (1999). Finally parody is also considered in terms of stage and production technique. Kane's Crave (1999) spotlights Beckett's and, posthumously, the Beckett estate's closure to experimentation in the staging of Beckett's plays.

Cet article présente l'œuvre de Sarah Kane, dramaturge britannique, comme une parodie du théâtre de Samuel Beckett. Kane faisait partie du mouvement théâtral "In-Yer-Face" qui se développa dans les années 1990 en Grande-Bretagne. Son style frontal rend hommage à celui qui fut son maître mais critique aussi la représentation des femmes chez l'écrivain de théâtre irlandais. Blasted (1995) de Kane peut en effet se lire comme une parodie de En Attendant Godot (1955), car elle y dénonce la domination masculine dans le monde de la presse tabloïde. Dans Blasted et 4.48 Psychose (1999), Kane remet en question la tendance de Beckett à contraindre le corps des femmes. L'article considère aussi la parodie en terme de mise en scène. Crave (1999) de Kane met en lumière la réticence à l'expérimentation scénique chez Beckett et, après sa mort, chez ceux qui gèrent son héritage.

\section{INDEX}

Mots-clés: parodie, genre, In-Yer-Face, hommage, critique, héritage, corps féminin oeuvrecitee Blasted, Crave, 4.48 Psychosis, Waiting for Godot, Not I Keywords: parody, gender, In-Yer-Face, homage, critique, legacy, female body

\section{AUTHORS}

\section{LARA COX}

Lara Cox teaches English in the department of Civil Engineering at Cergy Paris Université. Her interest in the post-Absurdist theatre of Sarah Kane builds on her work on the Theatre of the Absurd, the subject of her PhD (completed in 2012). She is the author of Afterlife of the Theatre of the Absurd: The Avant-garde, Spectatorship, and Psychoanalysis (Peter Lang, 2018). She has published 
on gender studies and modern and contemporary visual cultures in French, British, and US cultural contexts. 